Oldfield, S.J. ${ }^{1}$ and Day, D. (2012) Running Pedestrianism in Victorian Manchester. Social History Society, Annual Conference, Tuesday 3 - Thursday 5 April at the University of Brighton, Sussex.

In the absence of a national athletic organisation, sporting publicans were pivotal in the regulation and promotion of pedestrian events, attracting large crowds, regularly in their thousands, through the endorsement of local victuallers who supplied land for competitive races, organised the athletic calendar, and also posed as referee, time-keeper and prize giver during sporting contests. Pedestrianism, or foot-racing, provided sporting entertainment during much of the nineteenth century and publicans were quick to recognise the money making potential of such enterprises. Through entrepreneurial vision public houses were transformed into hubs for entertainment, offering a variety of activities to attract custom such as flower, fruit and vegetable shows, glee clubs, dramatics, sporting endeavours, and society meetings, thus cementing their place as integral to British leisure practices. By 1850, the drinks trade endorsed many sporting activities with the entrepreneurial landlord being fundamental to the survival of sport, especially within the industrial cities. In Manchester transport links enabled rural taverns and pubs to expand their clientele with business minded publicans featuring concert rooms, singing saloons and variety acts within their establishments, whilst inns which surrounded parks, such as Belle Vue and Pomona Gardens, offered live sport and further novelties. Sport moved to the rural outskirts and in areas such as Newton Heath, Hyde and Salford, where industrialisation had yet to impinge, popular Victorian gardens with attached public houses promoted and housed competitive athletic events. Arenas were built next to, and within, the grounds of the rural public houses and hotels, with many publicans enclosing their grounds in order to benefit financially through charging entrance fees, drink and food proceeds and betting commissions. The Royal Oak Park, Copenhagen Grounds and Salford Borough Gardens were all reputable running grounds established by their respective licensed victuallers, being attached to suburban Manchester pubs and hosting the majority of sporting events in the city until the 1880s when the organisation of amateur sport by the professional middle class led to a decline in professional activities. Not only did these arenas cater to the pedestrian crowds, they offered further sporting entertainments such as wrestling, rabbit coursing, pigeon shooting, quoits and pony trotting, which guaranteed attendance from the working class community. This paper investigates the relationship between pub and athletics within Manchester, considering the role of the publican in the promotion of sporting entertainments through individual case studies.

\footnotetext{
Miss Samantha-Jayne Oldfield is an associate lecturer in the Department of Exercise and Sport Science at Manchester Metropolitan University, completing her $\mathrm{PhD}$ in the field of sport history, creating collective biographies of Manchester sporting publicans during the mid-nineteenth century. She can be contacted on s.j.oldfield@mmu.ac.uk
} 


\section{Running Pedestrianism in Victorian Manchester}

Pedestrianism, or foot-racing, a well-established amusement in which large numbers of people took part, provided sporting entertainment during much of the nineteenth century. ${ }^{2}$ Traditionally pedestrian activities, including running, leaping and throwing events, became fashionable with the upper classes in fifteenth century Britain, ${ }^{3}$ and race-walking soon developed into a competitive activity during the seventeenth century when footmen of wealthy Earls and Lords competed for monies over set distances. However, it was the feats of individuals such as Foster Powell, Abraham Wood and Captain Barclay during the lateeighteenth and early-nineteenth centuries that captivated the public and helped to convert pedestrianism into a popular sporting pastime. ${ }^{4}$ Powell's 1773 wager to walk from London to York, and back again, in six days was widely reported in the British press, with the scene of his return on December $4^{\text {th }}$ being chaotic due to the public attention surrounding the event. ${ }^{5}$ Using the turnpike roads of England, Powell completed his journey in five days and eighteen hours and was greeted by 'three thousand people on foot, horseback, and in different carriages attending him from Highgate, accompanied with French horns', ${ }^{6}$ whilst further spectators lined the streets outside Hick's Hall, Middlesex, and eagerly awaited his arrival. ${ }^{7}$ However, as cities became increasingly industrialised, and land became developed, the space available for these activities dwindled. The absence of upper-class sponsors encouraged the entrepreneurs of the industrial cities to provide competition and financial backing for pedestrian matches to continue, and the sport moved to the racecourses of Britain where the increasingly influential middle-class businessmen could better control, organise and facilitate such events. ${ }^{8}$ Famously, Captain Barclay's 1000 miles in 1000 hours for 1000 guineas wager was performed on a marked section of the track at Newmarket in the presence of several thousand spectators' in $1809 .{ }^{9}$ Careful consideration was given to location, condition and construction of the half-mile course, with Barclay and his "team" ensuring the grass was short, the course smooth and even, and gas lamps were erected to illuminate the pathway for both competitor and spectators alike. ${ }^{10}$ Gambling encouraged

George M. Young, Early Victorian England 1830-1865 (Oxford: Oxford University Press, 1951).

Montague Sherman, Athletics and Football (London: Longmans, Greens \& Co., 1894).

Joseph Strutt, Glig-Gamena Angel-Deod, or, the Sports and Pastimes of the People of England (London: J White, 1801), 60-61; John A. Lucas, ed., 'Pedestrianism and the Struggle for the Sir John Astley Belt, 18781879', in John Apostal Lucas: Teacher, Sport Historian, and One who Lived his Life Earnestly. A Collection of Articles and Essays with an Autobiographical Sketch (Lemont, PA: Efrig Publishing, 2009), 9; Robert O. Ruhling \& John A. Hopkins, 'Race Walking', in Physiology of Sports, ed. Thomas Reilly, Niels Secher, Peter Snell and Clyde Williams (London: E \& F.N. Spon, 1990), 136.

5 Middlesex Journal and Evening Advertiser, December 4-7, 1773, n.p; Lloyd's Evening Post, December 3-6, $1773,543$.

6 General Evening Post, December 4-6, 1773, 1.

London Evening Post, December 4-7, 1773, n.p.

8 Dennis Brailsford, Sport, Time and Society: The British at Play (London: Routledge, 1991), 64; Adrian Harvey, The Beginnings of a Commercial Sporting Culture in Britain, 1793-1850 (Aldershot: As hgate, 2004), 134.

9 York Herald, May 13, 1809, n.p.; June 10, 1809, n.p.; July 15, 1809, n.p.; Oxford Journal, June 10, 1809, n.p.; Morning Chronicle, July 14, 1809, n.p.

10 The Times, June 15, 1809, 3; Peter Radford, The Celebrated Captain Barclay: Sport, Money and Fame in Regency Britain (London: Headline Book Publishing, 2001), 6-7. 
many to congregate at marked courses and race grounds in order to place their bet on sporting competitions, and, according to Brailsford, as the courses themselves were open, this became a valuable source of income for the course proprietors. ${ }^{11}$

By 1840 the sport gained in popularity through the endorsement of local publicans who promoted, and provided land for, competitive races. ${ }^{12}$ The notion that the enclosure of grounds was not considered before the nineteenth century ${ }^{13}$ has been challenged with research suggesting that eighteenth century entrepreneurs had already constructed sporting venues as early as the 1720s. Bellsize House, Hampstead, opened in April 1722 under the care of Mr Howell, providing a park with gardens and further entertainments for ladies and gentlemen of an 'agreeable' company, ${ }^{14}$ and George Smith's Artillery Grounds, Finsbury Square, provided cricket and pedestrian matches between c. 1740 and $1752 .^{15}$ The grounds were benched around the perimeter so no spectator could walk into the ring, ${ }^{16}$ and entrance fees were charged in accordance with the day's activities. ${ }^{17}$ The grounds became so popular that many tried to jump the walls to gain entry for free. ${ }^{18}$ However, due to the rising profile of pedestrian sport during the mid-nineteenth century, entrepreneurial publicans enclosed grounds specifically for sporting purpose on a much larger scale, creating a niche market for themselves as gatekeepers to working-class activities within the towns and cities of Britain. Although appearing to help rationalise recreation time, the innkeepers were 'fully aware of the profit-making potential of such an enterprise', ${ }^{19}$ with some establishments forming allegiances with specific sporting ventures in order to increase proceeds. ${ }^{20}$ Within London, the establishment of Hackney Wick changed the fortunes of pedestrianism within the metropolis, with proprietor James Baum enclosing one acre of land attached to the family-ran White Lion in 1857. The pear-shaped gravel running path of 260-yards presented an ideal base where activities including foot racing, wrestling and boxing could be enjoyed on the railway embankment for six-pence, or, for an additional cost, within the small pavilion at the top of the slightly uphill finishing straight. According to Roe, the early years at Hackney Wick were 'instrumental in reviving pedestrianism within London' and the

11 Dennis Brailsford, 'Sporting Days in Eighteenth Century England', Journal of Sport History, 9, no. 3 (1982): 43.

12 Geoffrey T. Vincent, '“Stupid, Uninteresting and Inhuman" Pedestrianism in Canterbury 1860-1885', Sporting Traditions 18, no. 1 (2001): 47; William J. Baker, 'The State of British Sport History', Journal of Sport History 10, no. 1 (1983): 59.

13 Dennis Brailsford, 'Sporting Days in Eighteenth Century England', Journal of Sport History, 9, no. 3 (1982): 43;

14 Daily Post, April 16, 1722, n.p; June 4, 1722, n.p.

15 London Evening Post, May 14-16, 1747, n.p.; August 22-25, 1752, n.p.; Morning Post, August 8, $1850,1$.

16 London Evening Post, July 24-26, 1744, n.p.

17 General Advertiser, June 8, 1748, n.p.

18 London Gazetteer, June 15, 1751, n.p.

19 Emma Lile, 'Professional Pedestrianism in South Wales during the Nineteenth Century', The Sports Historian 20, no. 2 (2000): 95.

20 Manchester Guardian, October 11, 1845, 12; Dennis Brailsford, British Sport: a Social History (Cambridge: The Lutterworth Press, 1997); Mike Huggins, The Victorians and Sport (London: Hambledon and London, 2004). 
proprietor's enthusiasm in promoting the events was vital to its success. ${ }^{21}$ The restoration of the sport within the metropolis saw an explosion in the construction of running grounds, all competing for the patronage of the city's spectators, but as the country expanded, sport spread to the provinces and many cities created a reputation as hubs for particular pedestrian activities. Within London traditional long-distance events continued to be popular, whereas Sheffield became home to the best short distance sprinters of the nineteenth century, and the middle-distance "milers" generated a vibrant and well-respected community within Manchester's city centre and neighbouring parishes. The London running grounds have been well documented, with Warren Roe's Front Runners detailing the arenas and their proprietors from 1857 to 1875 , and Paul Marshall's King of the Peds reciting the long-distance competitions and athletes of the late-nineteenth century, ${ }^{22}$ however, the same cannot be said for the northern cities of England, which had developed extensive pedestrian populations during this period. This paper will illuminate some of Manchester's pedestrian venues and their entrepreneurial proprietors, considering the role of publican in the survival of athletics within the city.

\section{Pedestrianism in Manchester}

Within Manchester, pedestrianism continued in the suburbs in places such as Newton Heath, Hyde and Salford where industrialisation had yet to impinge. ${ }^{23}$ Arenas were built next to, and within, the grounds of the local rural public houses and hotels, and some entrepreneurial publicans enclosed their grounds in order to reap the rewards through entrance fees, drink and food proceeds, and betting commissions. ${ }^{24}$ Although there were still reports of foot-racing occurring on the roads of Manchester, ${ }^{25}$ the majority of events moved to the purpose built stadia where publicans had control over the sport and athletes could be monitored.

Bell's Life reported Manchester as a 'notoriously sporting city' with pedestrian activities being 'the recreation of the hard-working artisans of the cotton metropolis', ${ }^{26}$ and the arenas designed for the sport in the 1850s and 1860s only reinforced the importance of such

21 Warren Roe, Front Runners: The First Athletic Track Champions (Sussex: The Book Guild Ltd, 2002), 22.

22 Warren Roe, Front Runners: The First Athletic Track Champions (Sussex: The Book Guild Ltd, 2002); Paul Marshall, King of the Peds (Milton Keynes: AuthorHouse UK, 2008).

23 Robina McNeil \& Michael Nevell, A Guide to the Industrial Archaeology of Greater Manchester (Telford: Association for Industrial Archaeology, 2000); N Burton, 'Leisure in the City: the Entertainment Sector in the Manchester Central Business District, 1770-1930', The Manchester Geographer, Journal of the Manchester Geographical Society 1980-1993 (1987): 15-32.

24 John Lowerson, Sport and the English Middle Classes (Manchester: Manchester University Press, 1995); Tony Collins and Wray Vamplew, Mud, Sweat and Beers: A Cultural History of Sport and Alcohol (Oxford: Berg Publishing, 2002).

25 Bell's Life in London and Sporting Chronicle, May 1, 1825, 141; April 28, 1833, n.p.; January 12, 1840, 7; November 12, 1843, 7; December 09, 1849, 7; January 16, 1853, 7.

26 Bell's Life in London and Sporting Chronicle, January 6, 1856, 6. 
endeavours, especially for the working-class community. Entrepreneurial publicans not only provided Manchester's athletic venues but also composed and held "articles of agreement", took bets, refereed, time-kept, and provided prizes. ${ }^{27}$ Many of Manchester's public houses were under the management of successful athletes, and this presented a base for which the performer could agree matches, promote their races, and showcase colours and trophies. Many sporting publicans became coaches and trainers of their own athletes who were usually housed within the hostelry, reinforcing the relationship between sport and the public house. $^{28}$ The traditional route for the licensed victualler emphasises the transition from athlete to publican, ${ }^{29}$ many of which then obtained running grounds or aligned with neighbouring venues. Along Oldham Road, between Manchester's city centre and Newton Heath, a community for pedestrianism formed with over forty sporting inns emerging between 1850 and 1870 during the peak of professional activities. The Royal Oak and Copenhagen Grounds, both established by their respective licensed victuallers and attached to suburban Manchester pubs located on the Oldham Road, hosted the majority of sporting events in the city until the mid-1870s when the organisation of amateur sport by the professional middle class led to a decline in professional activities. ${ }^{30}$

\section{Royal Oak and Copenhagen Grounds}

Established is 1857, the Copenhagen Grounds became one of leading sporting venues in Manchester during the mid-nineteenth century, hosting pedestrian, wrestling, rabbit coursing and pigeon shooting events, all under the watchful eye of Thomas Hayes. A professional middle-distance runner, "Tommy" Hayes, born in 1828 in Wolverhampton, moved to Middleton, Manchester, to pursue athletics in 1846, securing an illustrious career and becoming the leading runner over four miles. In 1852, the newly married Hayes moved to the Commercial Inn, Middleton where he conditioned athletes whilst continuing to compete in middle-distance events under the guidance of Walker, the "Rochdale Antelope". In 1857,

27 Geoffrey T. Vincent, '“Stupid, Uninteresting and Inhuman” Pedestrianism in Canterbury 1860 -1885', Sporting Traditions 18, no. 1 (2001): 47; William J. Baker, 'The State of British Sport History', Journal of Sport History 10, no. 1 (1983): 59.

28 In 1855, pedestrian trainer James Greaves took over the Ring of Bells where anyone attending foot races in Sheffield area would 'meet with every accommodation' according to Bell's Life in London and Sporting Chronicle, March 18, 1855, 6. Trainer "Choppy" Warburton, born James Edward, became landlord of The Fisher's Arms in Blackburn in 1877 (Richard O. Watson, 'Choppy' Warburton: Long Distance Runner and Trainer of Cycling Champions. Hero or Villain? (London: E Wiley Books, 2006)), and George Martin, exprofessional hurdler, housed athletes in his "stable" in Manchester before taking licence at the Royal Oak, Manchester, in 1864 (Samantha-Jayne Oldfield, 'George Martin, 'Wizard of Pedestrianism' and Manchester's Sporting Entrepreneur', Sporting Lives, ed. David Day (in press, Manchester: Manchester Metropolitan University Press, 2011), chapter 10).

29 Examples of which are detailed in Pierce Egan, Boxiana; or, Sketches of Ancient and Modern Pugilism, from the Days of the Renowned Broughton and Slack, to the Championship of Cribb: Volume 1 (London: George Virtue, 1830), 66, 121, 151, 270, 422-423, 476.

30 Peter G. Mewett, 'History in the Making and the Making of History: Stories and the Social Construction of a Sport', Sporting Traditions 17, no. 1 (2000): 2-3; Peter Bailey, Leisure and Class in Victorian England: Rational Recreation and the Contest for Control 1830-1885 (London: Redwood Burn, 1978). 
Hayes took licence at the Shear's Inn, located on the corner of Oldham Road and Shears Street, Newton Heath, two miles outside of Manchester city centre, where he began construction of a superior running ground in the land situated behind the public house. Costing approximately $£ 600$ and taking five months to construct, the Copenhagen Grounds opened on the $21^{\text {st }}$ March 1857 with over 3,000 spectators paying three-pence admission to view the perfectly straight and well-drained 750-yard circular track, with 235-yard straight 6yards wide, which was fully enclosed, 'except where the canal forms a boundary', by high wooden barriers. For an additional fee, upwards of 1,000 spectators could enjoy the 'substantial and commodious stand, from which an uninterrupted view of the contests is obtained'. Reports suggested that the grounds quickly gained a good reputation from both pedestrians and spectators alike, and ranked highly 'in the estimation of the lovers of sport in the locality in which it situates'. Hayes' marketing of the arena through newspaper endorsement meant that he no longer had time to continue training pedestrians, announcing his retirement in order to effectively promote foot racing at the ground, although continuing his own pedestrian pursuits as a veteran runner. Hayes developed the profile of athletes by gaining exclusive rights for several high-profile peds, most notably Thomas Horsepool who became the 'English Champion' and record holder for the mile in 1858, a novel marketing tool which encouraged attendance on match days. Taking the role of stakeholder, referee and timekeeper in numerous races, Hayes' constant presence and jolly disposition made the grounds a favoured venue for those in the sporting world.

Whilst Hayes promoted the Copenhagen Grounds, creating a reputation as a leading pedestrian and shooting venue, George Martin started to re-develop the image of pedestrianism by presenting a sporting entertainment like no other experienced in Great Britain. Martin himself was no stranger to the athletic world, born in 1826 in Hampshire, he practiced as a journeyman shoemaker before embarking on a sporting career under the care of Edward "Ned" Smith, the 'West-End Runner'. Moving to London in 1845, he begin training as a 120-yard sprinter and short distance hurdler to great avail. In 1849 Martin continued to pursue athletic competition by travelling to Manchester and resided with James Holden, the 'great stakeholder of Lancashire pedestrianism' and proprietor of White Lion public house. In 1851, Martin married Holden's eldest daughter, Alice, and took licence at the Plasterer's Arms, Gregson Street, Deansgate, where he announced his intention of training young pedestrian athletes. Through extensive endorsement, Martin procured a famed and wellrespected stable of pedestrians, and his reputation as a trainer was highly regarded, techniques congratulated and supporters would congregate to see his methods in practice. In 1861 Martin, John Nevin and Charles Mower, both champion distance runners, travelled to America to compete at the Fashion Race Course, New York, where the English duo remained undefeated, even with tough competition from Seneca Indian Louis "Deerfoot" Bennett. 
A 'marketing genius ahead of his time', Martin, aware of the interest which would surround Deerfoot with both the sporting and British public and press, encouraged Bennett to sail for England and proposed a tour of the athlete around the United Kingdom. ${ }^{31}$ Martin planned and financed the show, entitled the "Deerfoot Circus" which would see Bennett and several professional athletes compete in sporting feats as part of a travelling exhibition. Martin was known as the 'wizard of pedestrianism' within the press 'for his innovative ideas and promotional abilities', examples of which are clearly demonstrated through Deerfoot's competitions. $^{32}$ Martin had stakes in photographs of the Indian which were hung in public houses all over Britain, lithographs produced in Illustrated Sporting News and Theatrical and Musical Review, and the operetta "Deerfoot", which became a musical hit. ${ }^{33}$.

In May 1862 Martin informed the public that, 'having received so many application for Deerfoot to run at various parts of the country, and so few places being enclosed where a race can take place' he had constructed 'at an enormous expense... a travelling race course, twelve feet high, and nearly a quarter of a mile in circumference, so that a race can take place in any town where an even piece of ground can be selected'. ${ }^{34}$ Martin's canvas race course, 1,000ft in circumference, contained a 220 yard portable track for these demonstrations, which was transported by road to each venue, ${ }^{35}$ and the tour regularly attracted 4,000-5,000 spectators from all backgrounds. ${ }^{36}$ The races started each evening at six for the prices of one shilling within the amphitheatre and six-pence in the stand. ${ }^{37}$ However, as the weeks continued Martin began to struggle financially and trouble with the law ensued. Martin was prosecuted for assault, Bennett charged for strangling a spectator, ${ }^{38}$ and members of the "circus" staff were tried for robbery. ${ }^{39}$ Martin's athletes, being concerned with the growing number of illegalities, presented as witnesses against their manager, and on the 23 October 1862, William "American Deer" Jackson, with the support of his fellow performers, effectively sued Martin for lack of pay and poor living conditions. Throughout the hearing, and in the presence of numerous reporters, Jackson announced that the matches were fixed with Martin 'working' them in the Indian's favour and, as a result,

31 Rob Hadgraft, Deerfoot: Athletics' Noble Savage: from Indian Reservation to Champion of the World (London: Desert Island Books, 2007), 127.

32 The Era, 22 Sept. 1861, 9; Bell's Life in London and Sporting Chronicle, 2 July 1864, 4; Sports Quarterly Magazine, no. 6 (1978): 12-14; Edward Seldon Sears, Running Through the Ages (North Carolina: Macfarlane \& Co., 2001), 139.

33 Bell's Life in London and Sporting Chronicle, 22 Sept. 1861, 7; 22 June 1862, 2; Scotsman, 1 Apr. 1862, 1; Birmingham Daily Post, 18 Sept. 1862, 8.

34 Bell's Life in London and Sporting Chronicle, 11 May 1862, 7.

35 Illustrated Sporting News and Theatrical and Musical Review, 17 May 1862, 75; Era, 18 May 1862, 14.

36 Era, 18 May 1862, 14; Bell's Life in London and Sporting Chronicle, 18 May 1862, 7.

37 Scotsman, 18 Aug. 1862, 1.

38 Manchester Guardian, 12 Jan. 1863, 3; Penny Illustrated, 17 Jan. 1863, 43; Lancaster Gazette, and General Advertiser for Lancashire, Westmorland, Yorkshire \&c., 17 Jan. 1863, 6.

39 Hull Packet and East Riding Times, 13 June 1862, 6; Bedford Times, cited in Rob Hadgraft, Deerfoot: Athletics' Noble Savage: from Indian Reservation to Champion of the World (London: Desert Island Books, 2007), 133. 
interest in the extravaganza subsided, concluding on 10 September 1862, only five months after its launch. ${ }^{40}$

Undeterred, in November 1863, Martin returned to Manchester, retired as trainer and backer of pedestrians, and announced his intention to develop the grounds attached to the Royal Oak Hotel, Oldham Road-Fletcher Street, Newton Heath. ${ }^{41}$ Location was perfect; Miles Platting railway station was nearby, omnibuses and trams stopped within 200 yards of the ground, and it was less than half a mile from Thomas Hayes' renowned Copenhagen Running Grounds, with whom Martin had prior connections. Sixteen-acres of land were enclosed, with Martin spending $£ 2000$, approximately $£ 145,000$ by today's monetary value, to ensure the ground would be 'first class'. ${ }^{42}$ The Royal Oak Park boasted and 651 yard circular track, quarter of a mile straight course, a circular 750 yard rabbit course, a wrestling arena, bowling green, trotting course and grandstand all within the fenced enclosure which was capable of holding 20,000 people with ease. Further amenities included a shower-bath with soap, towels and brushes which could be used by the public for the sum of one penny, and a portable dressing room, with carpets and fittings, where athletes could 'strip by the fireside opposite the starting post'. ${ }^{43}$ A festival spirit was reported on opening day and the first event, a 'great mile race', was comprehensively promoted in the sporting press. ${ }^{44}$ In conclusion of the athletic events music played which 'greatly enlivened the proceedings' and the Era reported that the Royal Oak would, 'no doubt be the finest enclosed pedestrian ground in the kingdom'. 45

Reports of Manchester's sporting grounds being overpopulated were common, however, as pedestrianism started to lose credibility, the race grounds which survived did so by providing further amusements and testing innovative business ventures. ${ }^{46}$ Martin's grounds featured ornamental gardens with statues and sculptures, pianists and singers, aeronauts and photographers, as well as "live exhibits", such as Tonawanda Indian, "Steeprock", who resided in a wigwam in the centre of his newly constructed arena, and the Gypsy King, Queen and tribes who were displayed in a similar fashion. Alternatively, Hayes announced his retirement from pedestrianism in order to focus on the promotion of pigeon shooting and Cornish wrestling, breeding and selling pigeons for competition and designing equipment for

40 John Bull, 25 Oct. 1862, 685; Scotsman, 25 Oct. 1862, 3; Bell's Life in London and Sporting Chronicle, 26 Oct. 1862, 7; New York Clipper, 28 Oct. 1862, 284; Standard, 7 Nov. 1862, 3; Matthew Horace Hayes, Among Men and Horses (London: T. Fisher Unwin, 1894), 18.

41 Bell's Life in London and Sporting Chronicle, 28 Nov. 1863, 7.

42 Bell's Life in London and Sporting Chronicle, 22 Feb. 1857, 7; Era, 22 Feb. 1857, 9; 28 Nov. 1863, 7; 24 Apr. $1864,14$.

43 Illustrated Sporting News and Theatrical and Musical Review, April 9, 1864, 54; April 23, 1864, 77.

44 Era, 17 April 1864, 14.

45 Era, 24 Apr. 1864, 14.

46 Manchester Times, July 9, 1853, 3; Bell's Life in London and Sporting Chronicle, February 22, 1857, 7; Free Lance, February 8, 1868, n.p.; Robert J.R. Poole, 'Wakes Holidays and Pleasure Fairs in the Lancashire Cotton District, C.1790-1890' (PhD diss., Lancaster University, 1985), 159; Angus B. Reach, A Cotton-Fibre Halo: Manchester and the Textile Districts in 1849 (Hebden Bridge: Royd Press, 2008), 111. 
the wrestling circuit. With the Copenhagen Grounds being within the locality of the Royal Oak, Martin and Hayes worked in conjunction with each other to ensure profits and spectators migrated from stadium to stadium and their sporting entertainments became daylong affairs. ${ }^{47}$ Essentially, the sport declined due to the pressure of amateur organisations and concerns surrounding the publicans and their increased sporting authority, which 'could only have one conclusion, namely, the loss of confidence from the public and the ultimate collapse of the whole series of promotions'. ${ }^{48}$

After lease expired in 1869, the Copenhagen Grounds were destroyed with all railings, fixtures and boarding being sold at auction after the final race on $14^{\text {th }}$ June 1869 . Reports discussed the disappointment of this decision and Hayes was praised for his "honourable and straightforward manner in which the proceedings at these grounds have been conducted...during the twelve and a half years they have been in his possession'. ${ }^{49}$ Hayes, an 'enterprising proprietor' and local celebrity, continued to promote sport within Manchester, taking license at the Haymarket Hotel, Tonman Street, Deansgate, where he forged ties with managers at the Salford Borough Gardens, City Grounds and Royal Oak Park, continuing to be active within the sporting community until his death in 1894. Conversely, Martin's death in October 1865, aged 39, was a shock to the sporting community. Reports spread that Martin, had been suffering from 'mental afflictions' and on the $7^{\text {th }}$ September 1865, he was hospitalised at Wye House, a private asylum, 'for the care and treatment of the insane of the higher and middle classes', succumbing to mania less than one month later, his death at St Martins Workhouse Hospital, Middlesex being under 'deplorable circumstances'. His family was left penniless, with all of Martin's $£ 2000$ savings being left to his creditor, spirit merchant Joseph Fildes. Through charity and sporting benefits, funds were raised for Martin's widow and seven young children, and pedestrian friends continued his legacy, sharing the responsibilities involved in running the grounds until its eventual sale to Hayes' associate, John Cooper, in September 1866.

\section{Conclusion}

In conclusion, the 'reshaping of popular leisure was largely a phenomenon of the period after 1850 ', ${ }^{50}$ with many scholars focussing on the sporting infrastructure which emerged during this period, not the individuals who embraced sport and turned it into an lucrative business venture. Previously Holt's Sport and the British has detailed the leisure practices of the

47 Bell's Life in London and Sporting Chronicle, 11 June 1864, 7; Era, 30 July 1865, 14.

48 Charles L. Neil, Walking: A Practical Guide to Pedestrianism for Athletes and Others (London: C. Arthur Pearson Ltd., 1903), 19; David A. Jamieson, Powderhall and Pedestrianism (London: W. \& A.K. Johnston Ltd, 1943), 104.

49 Bell's Life in London and Sporting Chronicle, June 16, 1869, 7.

50 Adrian Harvey, The Beginnings of a Commercial Sporting Culture in Britain, 1793-1850 (Aldershot: Ashgate, 2004), 1. 
working-classes, whereas Lowerson's Sport and the English Middle Classes provides insight into the activities enjoyed by the upper-middle and lower-middle classes respectively, however there is very little research which discusses the grey area between the workingclass artisans and their influence in professional sport in Britain. Without the support of the entrepreneurial classes, the development of pedestrianism, especially within the city, would not have progressed. Previously, there has been an emphasis on the capital with little attention given to the impact of athletics in England's auxiliary cities and towns, however, pedestrianism was as popular, if not more so, within other industrial cities such as Manchester and the principles which surrounded the successful London running grounds being taken and applied around Great Britain with the relocation of entrepreneurial sportsmen. This paper should be used as a starting point in which to examine the impact of entrepreneurs, especially publicans, in the development of athletics and other sports outside of London, a topic that requires much further attention. 